\title{
Risk factors for ovarian postpartum resumption in Holstein cows, under high tropical conditions
}

\author{
Factores que afectan la reactivación ovárica postparto en vacas \\ Holstein, en el trópico alto
}

\author{
Humberto Guáqueta M,* MV, Jorge Zambrano V, Ph.D, Claudia Jiménez E, DVSc.
}

Universidad Nacional de Colombia, School of Veterinary Medicine and Animal Husbandry, Department of Sciences for Animal Health, Animal Reproduction And Herd Health Research Group. Edificio 561B, Carrera 30 No. 45-03 Bogota, Colombia. *Correspondence: hguaquetam@unal.edu.co

Received: April 2013; Accepted: November 2013.

\begin{abstract}
Objective. To evaluate the factors associated with postpartum ovarian resumption and follicular dynamics in Holstein cows under high altitude conditions (2,600 masl). Materials and methods. Forty-five Holstein cows were studied between 14 days before and 120 days after calving. Uterine involution, follicular dynamics, serum progesterone and peripartum pathologies were evaluated; additionally, body condition (BC), calving type, milk yield, were also evaluated. According to hormonal and reproductive findings, cows were classified into two groups: early ovarian resumption (EOR) or delayed ovarian resumption (DOR). Results. The occurrence of the first follicular for EOR animals $(n=31)$ was produced on average $9.58 \pm 3.45$ days postpartum and was similar to the DOR group $(n=10)$ [10.8 \pm 4.83 days; $p>0.05)]$. The first postpartum ovulation occurred at $21.55 \pm 5.90$ days (EOR) and was significantly delayed $(48.7 \pm 27.85$ days) for DOR animals $(p<0.05)$. Thirty-six point five percent of the cows $(n=f)$ had normal estrus cycles (18 to 24 days), while $63.5 \%(n=26)$ showed dysciclia. The factors associated with ovarian resumption and cyclicity were the loss of $B C[\mathrm{OR}=3.3$, CI 95\% (1.2-13.3) $(p<0.05)]$ and lameness [OR=9.0, CI 95\% $(1.2-13.3)(p<0.05)]$. Conclusions. Although the emergence of postpartum follicular waves was observed early, under the experimental conditions of this study there are factors that may affect the first ovulation favoring the occurrence of anovulatory conditions. The determinant factors were low body condition and lameness.
\end{abstract}

Key words: Anovulation, ovarian follicle, postpartum (Source: DeCS).

\section{RESUMEN}

Objetivo. Evaluar los factores asociados con la reactivación ovárica y la dinámica folicular postparto en vacas de la raza Holstein bajo condiciones de altura (2600 msnm). Materiales y métodos. Cuarenta y cinco vacas Holstein fueron estudiadas entre 14 días preparto y 120 días posteriores al mismo. Fueron evaluadas la involución uterina, dinámica folicular, progesterona sérica y presentación de patologías en el periparto; adicionalmente la condición corporal (CC), tipo de parto y producción de leche. De acuerdo con los hallazgos reproductivos y hormonales, las vacas se agruparon en dos grupos: reactivación ovárica temprana (ROT) o retardada (ROR). Resultados. La emergencia de la primera onda folicular para animales ROT $(n=31)$, ocurrió en promedio $9.58 \pm 3.45$ días postparto y fue 
similar a los ROR $(n=10)$ [10.8 44.83 días $(p>0.05)]$. La primera ovulación postparto se observó a los $21.55 \pm 5.90$ días (ROT) y fue significativamente más demorada (48.7 \pm 27.85 días) para los animales ROR $(p<0.05)$. El $36.5 \%$ de los animales $(n=f)$ presentaron ciclos estrales normales (18 a 24 días), mientras que el $63.5 \% \quad(n=26)$ mostraron disciclia. Los factores asociados con la reactivación ovárica y la ciclicidad fueron la pérdida de CC $[O R=3.3$, IC $95 \%(1.2-13.3)(p<0.05)]$ y la presentación de cojeras $[O R=9.0$, IC $95 \%(1.2-13.3)(p<0.05)]$. Conclusiones. Aunque la emergencia de ondas foliculares postparto se presentó de manera rápida, bajo las condiciones experimentales del presente estudio, existen factores que afectan la primera ovulación favoreciendo la presentación de condiciones anovulatorias. La presentación de cojeras, y la pérdida de CC postparto fueron factores determinantes.

Palabras clave: Anovulación, folículo ovárico, postparto (Fuente: DeCS).

\section{INTRODUCCIÓN}

La eficiencia reproductiva es un reto para las ganaderías y los productores de leche en el mundo. Uno de los principales problemas en los hatos es el retraso en el reinicio de la actividad ovárica después del parto. Para obtener el intervalo entre partos (IEP) ideal de doce meses, los animales deben concebir dentro de los 85 días posteriores al parto, lo cual requiere que hayan normalizado su ciclicidad (1). Esto constituye un evento crítico para lograr un desempeño reproductivo eficiente y minimizar las pérdidas económicas representadas en el incremento en el número de días abiertos y servicios por concepción.

Los patrones de crecimiento y dinámica de los folículos han sido descritos ampliamente en bovinos postparto. Mientras que en algunos animales no se evidencia actividad ovárica normal (anestro), otros muestran ondas de desarrollo y crecimiento de folículos que no son ovulados, generando diferentes tipos de anestro $(2,3)$.

Algunos autores han descrito la emergencia de la primera onda $(4,5)$; otros, han determinado el diámetro y tamaño de las estructuras ováricas con respecto a la fase de desarrollo de la misma (6). También se han investigado los efectos que tienen la presentación de patologías frecuentes en bovinos de leche (mastitis, retención de membranas fetales, metritis, hipocalcemia puerperal, cetosis y cojeras) durante el postparto sobre la dinámica ovárica y la fertilidad, reportándose relaciones importantes entre la presentación de dichas patologías y el pobre desempeño reproductivo (7-9).

En Colombia se han realizado algunas investigaciones referentes a la dinámica folicular y reactivación ovárica postparto, aunque la mayoría de ellas han sido principalmente con animales Bos indicus $(10,11)$. Son escasos en el país los trabajos orientados a caracterizar la dinámica folicular y ovárica durante el postparto en bovinos Holstein de alta producción y selección genética $(12,13)$.

\section{INTRODUCTION}

Reproductive efficiency is a challenge for breeders and milk producers around the world. One of the main problems for farms is the delay in the resumption of postpartum ovarian activity. To obtain the ideal interval between calving (IBC) of twelve months, animals must conceive within 85 days after partum, which requires the normalization of their cyclicity (1). This is a critical event for achieving efficient reproductive performance and minimizing economic losses represented in the increase in the number of open days and services per conception.

Growth patterns and follicle dynamics have been widely described in postpartum bovines. While some animals did not show normal ovarian activity (anestrus), others show development and growth waves of follicles that are not ovulated, generating different types of anoestrus $(2,3)$.

Some authors have described the emergence of the first wave $(4,5)$; others have determined the diameter and size of the ovarian structures with respect to the development phase of the same (6). The effects of common pathologies in dairy bovines have also been investigated (mastitis, retention of fetal membranes, metritis, puerperal hypocalcemia, ketosis and lameness, ) on ovarian dynamics and fertility during postpartum, reporting important relationships between the occurrence of such pathologies and poor reproductive performance (7-9).

In Colombia there have been some investigations relating to follicular dynamics and postpartum ovarian resumption, although most of them have been mainly with Bos indicus animals $(10,11)$. The studies conducted in the country for characterizing follicular and ovarian dynamics during postpartum in high yield Holstein bovines and genetic selection are scarce $(12,13)$. 
Los objetivos del presente estudio fueron evaluar de manera prospectiva algunos de los factores asociados con la reactivación ovárica postparto en un hato especializado de vacas de la raza Holstein, bajo condiciones de trópico alto y caracterizar los patrones de reactivación ovárica y la dinámica folicular postparto.

\section{MATERIALES Y MÉTODOS}

Sitio de estudio y animales. El estudio se realizó en una explotación lechera de la Sabana de Bogotá, a una altura de 2565 msnm., con precipitación anual de $698 \mathrm{~mm}$ y temperatura promedio de $14^{\circ} \mathrm{C}$, que corresponde a una región del trópico situada a más de 2000 msnm, con temperaturas bajas y cambios significativos entre el día y la noche (14). En un hato de 230 animales de Holstein bajo un sistema de pastoreo rotacional kikuyo (Pennisetum clandestinum) y ryegrass (Lollium multiflorum), suplementados con concentrado y sales minerales comerciales y ordeñados dos veces al día. Del total de animales $(n=230)$ se escogió una muestra de 45 , los cuales fueron evaluados por primera vez dos semanas antes del parto, registrándose su estado general de salud y condición corporal; también se llevó un registro de todos los eventos de salud y tipo de parto. A partir de ese momento, fueron objeto de un examen clínico-reproductivo cada tercer día, hasta el momento en que recibieron su primera inseminación postparto o hasta que completaron 120 días del parto.

Condición corporal. La condición corporal (CC) fue evaluada durante todo el periodo del estudio utilizando una escala de 1-5 ( 1 =delgada, 5=obesa) (15). Los días más importantes usados en el analisis de la CC fueron, dos semanas antes de la fecha esperada de parto y los días 30 y 60 postparto (2).

Producción de leche. La producción de leche fue registrada por medio de los medidores del equipo de ordeño (Westfalia-Surge ${ }^{\circledR}$, mini True-test ${ }^{\circledR}$ Wellington, New Zealand). La información pertinente al monitoreo productivo y reproductivo del hato fue almacenada en el software Interherd ${ }^{\circledR}$, Versión 2-10-10, de InterAgri-Animal Information Management Systems Limited, UK. (Pan Livestock Services). Se recolectaron los datos correspondientes al promedio diario de producción de leche al día 28 y 60 post-parto; así como la producción final ajustada a 305 días para cada uno de los animales.

Dinámica folicular y seguimiento de la ovulación. Con el fin de agrupar los animales con relación al momento de la reactivación ovárica, se utilizó el promedio general y la desviación estándar
The objectives of this study were to prospectively evaluate some of the factors associated with postpartum ovarian resumption in a specialized Holstein cow farm, under high tropical conditions and characterize postpartum ovarian resumption patterns and follicular dynamics.

\section{MATERIALS AND METHODS}

Study site and animals. The study was conducted in a dairy farm in the Sabana de Bogota, at a height of 2565 meters, with annual rainfall of $698 \mathrm{~mm}$ and average temperature of $14^{\circ} \mathrm{C}$, which corresponds to a region of the tropics located above 2,000 masl, with low temperatures and significant changes between day and night (14). In a farm of 230 Holstein cows under a kikuyo (Pennisetum clandestinum) and ryegrass (Lollium multiflorum) rotational grazing system, supplemented with concentrate and commercial mineral salts and milked twice a day. Of the total number of animals $(n=230)$ a sample of 45 was chosen, which were evaluated for the first time two weeks before partum, recording their general health and body condition; a record of all health events and type of calving was also made. From that moment, they were subject to clinicalreproduction examination every other day, until they received their first postpartum insemination or until 120 days from calving have been completed.

Body condition. The body condition (BC) was assessed during the entire period of the study using a scale from 1 to 5 (1=thin, 5 =obese) (15). The most important days used in the BC analysis were two weeks before the expected date of partum and day 30 and 60 postpartum (2).

Milk production. Milk production was recorded using the gauges of the milking equipment (Westfalia-Surge ${ }^{\circledR}$, mini True-test ${ }^{\circledR}$ Wellington, New Zealand). The information relevant to the productive and reproductive monitoring of the farm was stored in the Interherd ${ }^{\circledR}$ software, Version 2-10-10, of InterAgri-Animal Information Management Systems Limited, UK. (Pan Livestock Services). The data corresponding to the daily average of milk production at day 28 and 60 postpartum was collected; as well as the final production adjusted to 305 days for each animal.

Follicular dynamics and ovulation monitoring. In order to group animals in relation to the time of ovarian resumption, the general average and standard deviation 
(32 $\pm \mathrm{DE})$ de los días a la primera ovulación postparto. Este dato se utilizó como punto de corte para agrupar los animales en dos categorías: aquellos con reactivación ovárica temprana y ovulación antes del día 32 (ROT); y aquellos con reactivación ovárica retardada (ROR) ya que su ocurrencia sucedió posterior al día 32 postparto. La duración del ciclo estral, posterior a la primera ovulación, fue considerada como normal cuando los ciclos tuvieron una duración entre 18 y 24 días, o alterada (disciclia) cuando los intervalos entre dos estros consecutivos fueron menores a 17 o mayores de 25 días $(3,6)$. El reinicio de la actividad ovárica fue determinado por la emergencia de la primera onda folicular post parto (folículos con diámetros $\geq 5 \mathrm{~mm}$ ); los folículos dominantes fueron seguidos por ultrasonido hasta cuando presentaron atresia u ovulación. La ovulación fue definida como la desaparición del folículo preovulatorio procedente de la última onda de desarrollo folicular y la subsiguiente aparición de un cuerpo lúteo $(\mathrm{CL})$ (16), así como el incremento en los niveles de progesterona $\left(P_{4}\right)$ sérica $\geq 1 \mathrm{ng} / \mathrm{ml}$ (17).

El seguimiento clínico reproductivo se llevó a cabo mediante palpación rectal y ultrasonografía cada tercer día; éstas fueron realizadas con un equipo portátil (Agroscan-L ${ }^{\circledR}$ ECM, France) equipado con transductor lineal de $5.0 \mathrm{MHz}$. Todos los folículos $\geq 5 \mathrm{~mm}$., así como las estructuras luteales fueron registrados en mapas ováricos, adaptados de acuerdo con la metodología descrita en trabajos previos $(4,5)$ y algunos modelos sugeridos (18). El tamaño de los folículos y cuerpos lúteos con diámetros mayores de $5 \mathrm{~mm}$ fue registrado de acuerdo con las metodologías descritas en estudios similares (19-21). Las estructuras ováricas observadas desde una sola imagen congelada fueron medidas cuando se visualizó el área máxima aparente en cada una de ellas. El volumen del cuerpo lúteo $(\mathrm{VCL})$ se calculó por medio de la fórmula $\mathrm{VCL}=4 / 3 \times \pi \times \mathrm{r}^{3}$, donde el radio ( $r$ ) fue calculado con la fórmula $r=(L / 2+A / 2) / 2$ (21). La actividad luteal fue evidenciada por la observación de dos muestras consecutivas de progesterona sérica con concentraciones superiores a $1 \mathrm{ng} / \mathrm{ml}$ (20-22). Los datos obtenidos fueron normalizados con relación al momento de la primera ovulación post parto. El anestro fue definido como la ausencia de actividad luteal después de haber realizado el seguimiento ultrasonográfico y confirmado por los niveles basales de progesterona en sangre $(<1 \mathrm{ng} / \mathrm{ml})$ y ausencia de cuerpo lúteo $(6,23)$.

Muestras de sangre y orina. Durante las evaluaciones se recolectaron muestras de sangre por punción de la vena coccígea, utilizando tubos al vacío sin anticoagulante (Vacutainer ${ }^{\circledR}$,
$(32 \pm D E)$ of the days of the first postpartum ovulation was used. This data was used as a cutoff point for grouping animals into two categories: those with early ovarian resumption and ovulation before day 32 (EOR); and those with delayed ovarian resumption (DOR) since its occurrence happened after day 32 postpartum. The duration of the estrous cycle after the first ovulation was considered normal when cycles lasted between 18 and 24 , or altered (dysciclia) when the interval between two consecutive estrous were less than 17 or greater than 25 days $(3,6)$. The resumption of ovarian activity was determined by the emergence of the first postpartum follicular wave (follicles with diameters $\geq 5$ $\mathrm{mm}$ ); dominant follicles were followed with ultrasound until atresia or ovulation. Ovulation was defined as the disappearance of the preovulatory follicle from the last follicular development wave and the subsequent emergence of a corpus luteum (CL) (16), as well as the increase in serum progesterone $\left(\mathrm{P}_{4}\right)$ levels $\geq 1 \mathrm{ng} / \mathrm{ml}$ (17).

The monitoring of the reproductive clinical was carried out by rectal palpation and ultrasonography every other day; these were performed with a portable equipment (Agroscan-L ${ }^{\circledR}$ ECM, France) equipped with a $5.0 \mathrm{MHz}$ linear transducer. All follicles $\geq 5 \mathrm{~mm}$ as well as luteal structures were recorded in ovarian maps, adapted in accordance with the methodology described in previous studies (4.5) and some suggested models (18). The size of follicles and corpus luteum with diameters larger than $5 \mathrm{~mm}$ was recorded in accordance with the methodologies described in similar studies (19-21). Ovarian structures observed from a single frozen image were measured when the maximum apparent area in each of them was visualized. The volume of the corpus luteum (VCL) was calculated using the formula $\mathrm{VCL}=4 / 3 \times \pi \times \mathrm{r}^{3}$, where the radius ( $r$ ) was calculated with the $r=(L / 2+A / 2) / 2$ (21). Luteal activity was evidenced by the observation of two consecutive samples of serum progesterone with concentrations higher than $1 \mathrm{ng} / \mathrm{ml}$ (20-22). Data was normalized with respect to the time of the first postpartum ovulation. Anestrus was defined as the absence of luteal activity after ultrasound and confirmed by basal progesterone levels in blood $(<1 \mathrm{ng} / \mathrm{ml})$ and absence of corpus luteum $(6,23)$.

Blood and urine samples. During the evaluations, blood samples were collected by puncturing the coccygeal vein, using vacuum tubes without anticoagulant (Vacutainer ${ }^{\circledR}$, Becton-Dickinson, Rutherford, NJ, USA). 
Becton-Dickinson, Rutherford, NJ, USA). Una vez colectadas fueron refrigeradas y transportadas hasta el laboratorio donde se centrifugaron a 3000 rpm durante 20 minutos para separar el suero, que fue fraccionado y almacenado en tubos Eppendorf $\mathrm{a}-70^{\circ} \mathrm{C}$ hasta realizar la medición de las concentraciones de calcio y progesterona.

Durante la primera y segunda semana postparto se colectaron dos muestras de orina con intervalos de siete días entre ellas, con el fin de determinar los niveles de cuerpos cetónicos por medio de tiras reactivas (Bayer, Reagent strips for Urianalysis: Multistix ${ }^{\circledR}$ 10SG. Siemens Healthcare Diagnostics Inc. Los Angeles, CA 90045 USA).

Medición de progesterona sérica. La medición de los niveles séricos de progesterona se realizó por la técnica de radioinmunoanálisis en fase sólida (RIA), utilizando los kits Coat-A-Count Progesterone ${ }^{\circledR}$ (Siemens Healthcare Diagnostics Inc. Los Angeles, CA 90045 USA), con una sensibilidad analítica de $0.02 \mathrm{ng} / \mathrm{ml}$. y una reactividad cruzada del $100 \%$ para $\mathrm{P}_{4}$ pero muy baja con otros esteroides de producción natural o medicamentos presentes en la muestra. Las concentraciones de progesterona fueron medidas en alícuotas separadas según los procedimientos sugeridos por los productores del kit, en el Laboratorio de hormonas de la Facultad de Medicina Veterinaria y de Zootecnia de la Universidad Nacional de Colombia. Los resultados obtenidos fueron impresos, expresados en niveles de radiactividad, por lo que posteriormente debieron ser transcritos al software RIAPC ${ }^{\circledR}$ para permitir su cuantificación en nanogramos por mililitro $(\mathrm{ng} / \mathrm{ml})$. Los Coeficientes de variación intra-ensayo e interensayo fueron de $7.8 \%$ y $4.7 \%$ respectivamente.

Detección de estros e inseminación artificial. La detección de estros se realizó por el método de observación visual, tres veces al día, en períodos de al menos 15 minutos cada uno, donde se registró cualquier actividad de monta o intentos de la misma, así como alguno de los signos del estro (descargas vaginales o presencia de moco, olfateo y seguimiento de otras vacas). El estro fue definido como la permanencia de un animal para ser montado por otro durante algunos segundos, conducta denominada monta estática (24). El período de espera voluntario (PEV) establecido en la finca fue de 50 días. Todos los animales que cumplían con el PEV habiendo aprobado las evaluaciones reproductivas previas, fueron inseminados una vez detectados en estro, de acuerdo con el sistema am/pm $(24,25)$.

Descripción de las variables. Las variables se categorizaron de la siguiente manera: 1) condición corporal (CC) pre y postparto (escala de 1-5); 2) concentración sérica de calcio pre y postparto
Once collected, they were refrigerated and transported to the laboratory where they were centrifuged at $3000 \mathrm{rpm}$ for 20 minutes to separate the serum, which was fractioned and stored in Eppendorf tubes at $-70^{\circ} \mathrm{C}$ until the measurement of calcium and progesterone concentrations.

During the first and second week postpartum, two urine samples were collected with intervals of seven days between them, in order to determine the levels of ketones using reagent strips (Bayer, Reagent strips for Urianalysis: Multistix ${ }^{\circledR}$ 10SG. Siemens Healthcare Diagnostics Inc. Los Angeles, CA 90045 USA).

Serum progesterone measurement. The measurement of serum progesterone levels was carried out through the solid-phase radioimmunoassay technique (RIA), using the kits Coat-A-Count Progesterone ${ }^{\circledR}$ (Siemens Healthcare Diagnostics Inc. Los Angeles, CA 90045 USA), with an analytical sensitivity of $0.02 \mathrm{ng} / \mathrm{ml}$. and cross reactivity of $100 \%$ for $\mathrm{P}_{4}$ but very low with other naturally produced steroids or drugs present in the sample. Progesterone concentrations were measured in aliquots separated according to the procedures suggested by the producers of the kit, in the hormone laboratory of the Faculty of Veterinary Medicine and Animal Husbandry of Universidad Nacional de Colombia. The results were printed, expressed in radioactivity levels, so they had to be subsequently transcribed to the RIAPC ${ }^{\circledR}$ software to allow their quantification in nanograms per milliliter $(\mathrm{ng} / \mathrm{ml})$. Intra-assay and inter-assay variation coefficients were $7.8 \%$ and $4.7 \%$, respectively.

Detection of estrus and artificial insemination. The detection of estrus was performed through the visual observation method, three times a day, in periods of at least 15 minutes each, where any breeding activity of or attempts thereof were registered, as well as some of the signs of estrus (vaginal discharges or presence of mucus, sniffing and following of other cows). Estrus was defined as the permanence of an animal to be mounted by another for a few seconds a conduct known as static breeding (24). The voluntary waiting period (VWP) established in the farm was 50 days. All animals that met the VWP, having approved the previous reproductive assessments, were inseminated once detected in estrus, in accordance with the am/pm system $(24,25)$.

Description of variables. Variables were categorized as follows: 1) body condition (BC) before and after partum (1-5 scale); 2) calcium 
(mg/dL), 3) tipo de parto (normal o distócico); 4) número de partos (primer y segundo parto contra animales de tercer o más partos); 5) diámetro de las estructuras ováricas (folículos $\geq 5 \mathrm{~mm}$ y cuerpos lúteos $(\mathrm{mm}) ; 6)$ diámetro de de los cuernos a nivel de la bifurcación $(\mathrm{mm}) ; 7)$ producción diaria de leche (Kg/leche/vaca/día); 8) presentación de enfermedades puerperales: hipocalcemia, cetosis, retención de placenta, metritis puerperal, mastitis, quistes ováricos, cojeras, y fiebre; 9) aplicación de tratamientos post-parto 10) concentraciones séricas de progesterona $(\mathrm{ng} / \mathrm{ml}$ en sangre) y 11$)$ días a la primera ovulación postparto.

Análisis estadístico. La información obtenida en los exámenes ultrasonográficos de los ovarios y las concentraciones séricas de progesterona fueron analizadas inicialmente realizando estadística descriptiva, comparación de promedios y estableciendo diferencias entre los grupos de animales. Los datos fueron normalizados con relación al momento de la ovulación y posteriormente analizados utilizando el Modelo General Lineal de medidas repetidas. El análisis de los factores asociados con la reactivación ovárica postparto como CC, calcio sérico, tipo de parto, número de partos, presentación de enfermedades metabólicas periparto (hipocalcemia o cetosis), presentación de patologías y la producción de leche se llevó a cabo primero a través de un análisis univariado con tablas de contingencia de $2 \times 2$; luego se seleccionaron las variables que resultaron significativas a través de la prueba de Chi cuadrado $(p<0.05)$, dichas variables fueron incluidas en un modelo final de Regresión Logística Binaria para determinar las variables asociadas con la primera ovulación postparto. La fortaleza de la asociación se estimó a través del cálculo del Odds Ratio (OR) con su respectivo intervalo de confianza del $95 \%$. Todo valor $\mathrm{p}<0.05$ fue considerado significativo. Los análisis estadísticos fueron realizados por medio del software SPSS ${ }^{\circledR}$ versión 17.0.

\section{RESULTADOS}

Dinámica folicular y primera ovulación postparto. La emergencia de la primera onda folicular postparto se observó en promedio al día 10.1 13.45 . El $39 \%$ de los animales $(n=16)$ presentó dicha emergencia entre los días 4 y 8 postparto, mientras que en el $46.3 \%(n=19)$ se observó entre los días 9 y 13 , y en el $14.6 \%(n=6)$ sucedió entre el día 14-20. Todos los animales reiniciaron su dinámica folicular antes del día 20 postparto.

El promedio de días a la primera ovulación fue de 24.26士7.84 (rango de 13-41). Con fines del serum concentration before and after partum $(\mathrm{mg} / \mathrm{dL}), 3)$ calving type (normal or dystocias); 4) number of births (first and second birth versus animals with three or more births); 5) diameter of ovarian structures (follicles $\geq 5 \mathrm{~mm}$ and corpora lutea $(\mathrm{mm}), 6)$ diameter of horns at the fork $(\mathrm{mm})$; (7) daily milk production $(\mathrm{Kg} / \mathrm{milk} / \mathrm{cow} /$ day $) ; 8)$ occurrence of puerperal disease: hypocalcemia, ketosis, retained placenta, puerperal metritis, mastitis, ovarian cysts, lameness and fever; 9) application of postpartum treatments; 10$)$ serum progesterone concentrations ( $\mathrm{ng} / \mathrm{ml}$ in blood); and 11 ) days to the first postpartum ovulation.

Statistical analysis. The information obtained from the ultrasound tests of ovaries and serum progesterone concentrations were initially analyzed by descriptive statistics, comparison of averages and establishing differences between the animal groups. The data was normalized with respect to the time of ovulation and subsequently analyzed using the repeated measures General Linear Model. The analysis of the factors associated with postpartum ovarian resumption such as CC, serum calcium, calving type, number of births, peripartum metabolic diseases (hypocalcemia or ketosis), pathologies and milk production, was first carried out through a univariate analysis with $2 \times 2$ contingency tables; then the variables that were significant according to the Chi square test $(p<0.05)$ were selected, these variables were included in a final Binary Logistic Regression model to determine the variables associated with the first postpartum ovulation. The strength of the association was estimated by calculating the Odds Ratio (OR) with its respective $95 \%$ confidence interval. Every $p<0.05$ value was considered significant. Statistical analyses were performed using SPSS $^{\circledR}$ software version 17.0.

\section{RESULTS}

Follicular dynamics and first postpartum ovulation. The emergence of the first postpartum follicular wave was observed on average on day $10.1 \pm 3.45$. Thirty-nine percent of animals $(n=16)$ showed such emergence between days 4 and 8 postpartum, while in $46.3 \%(n=19)$ it was observed between days 9 and 13 , and in $14.6 \%(n=6)$ it took place between day 14-20. All the animals resumed their follicular dynamics before day 20 postpartum.

The average number of days to the first ovulation was $24.26 \pm 7.84$ (range from 13 to 41 ). For 
análisis estadístico y con base en este promedio más una desviación estándar, se definió el día 32 como promedio de días a la primera ovulación postparto, el cual fue utilizado como punto de corte para definir dos categorías: Los animales ROT $(n=31)$ y los animales ROR $(n=10)$, (Tabla 1$)$.

En general, el intervalo entre el parto y la primera ovulación, y el parto y las ovulaciones siguientes (segunda, tercera y cuarta) entre los individuos ROT y ROR fueron estadísticamente diferentes $(p<0.05)$. Sin embargo, no se observaron diferencias significativas en cuanto a los intervalos entre dos ovulaciones consecutivas (interovulatorios) entre los animales con ROT y ROR ( $p>0.05)$. Los individuos del grupo ROT presentaron menor diámetro del folículo ovulatorio tanto en el primero como en los cuatro ciclos subsiguientes $(18.07 \pm 5.0 \mathrm{~mm}, 21 \pm 4.4 \mathrm{~mm}, 21.8 \pm 3.2 \mathrm{~mm}$ y $21.9 \pm 3.2 \mathrm{~mm})$, comparados con los del grupo ROR durante los mismos períodos $(23.1 \pm 5.2 \mathrm{~mm}$, $23.8 \pm 5.9 \mathrm{~mm}, 24.8 \pm 8.8 \mathrm{~mm}$ y $35.4 \pm 10.4 \mathrm{~mm}$ ). Esta diferencia en el diámetro del folículo ovulatorio no fue significativa al momento de la primera ovulación posparto, pero si en las tres ovulaciones sub-siguientes $(p \leq 0.05)$.

De un total de 146 ovulaciones registradas por ultrasonido, solamente se visualizaron 53 estros, lo cual corresponde a un porcentaje de detección de $36 \%$.

Actividad ovárica post-ovulación. Un total de veintisiete animales (65.9\%) mostraron ciclicidad normal después de la primera ovulación postparto con presentación de ciclos estrales de 18-24 días de duración, mientras que el $(34.16 \%),(n=14)$ se mostraron acíclicos durante los primeros 67 días, incluyendo anovulación por condiciones quísticas ováricas $(n=2)$, anovulación por $\mathrm{CL}$ persistente $(n=8)$ y desarrollo folicular con incapacidad para alcanzar un diámetro ovulatorio $(n=4)$. statistical analysis purposes and based on this average plus one standard deviation, day 32 was defined as the average number of days to the first postpartum ovulation, which was used as a cutoff point for defining two categories: EOR animals $(n=31)$ and DOR animals $(n=10)$, (Table 1$)$.

Overall, the interval between calving and the first ovulation, and calving and the following ovulation (second, third and fourth) between EOR and DOR individuals, were statistically different $(p<0.05)$. However, there were no significant differences in the interval between two consecutive ovulations (interovulatory) between animals with EOR and DOR ( $p>0.05)$. Individuals in the EOR group had a smaller ovulatory follicle diameter both in the first as in the subsequent four cycles $(18.07 \pm 5.0 \mathrm{~mm}$, $21 \pm 4.4 \mathrm{~mm}, 21.8 \pm 3.2 \mathrm{~mm}$ and $21.9 \pm 3.2 \mathrm{~mm}$ ), when compared with those of the DOR group during the same periods $(23.1 \pm 5.2 \mathrm{~mm}, 23.8 \pm 5.9 \mathrm{~mm}$, $24.8 \pm 8.8 \mathrm{~mm}$ and $35.4 \pm 10.4 \mathrm{~mm}$ ). This difference in ovulatory follicle diameter was not significant at the time of the first postpartum ovulation, but it did in the three subsequent ovulations $(p \leq 0.05)$.

Of a total of 146 ovulations recorded with ultrasound only 53 estrus were visualized, which corresponds to a detection percentage of $36 \%$.

Post-ovulation ovarian activity. A total of twenty-seven animals (65.9\%) showed normal cyclicity after the first postpartum ovulation with estrus cycles of 18-24 days, while $34.16 \%(n=14)$ were acyclic during the first 67 days, including anovulation by ovarian cystic conditions $(n=2)$, Anovulation by persistent $C L$ $(\mathrm{n}=8)$ and follicular development with inability to achieve ovulatory diameter $(n=4)$.

Table 1. Differences in postpartum follicular dynamics in Holstein cows that showed Early Ovarian Resumption (EOR) as compared to those that showed Delayed Ovarian Resumption (DOR) in the high tropics (Sabana de Bogota).

\begin{tabular}{|c|c|c|c|}
\hline Variable & $\begin{array}{c}\text { EOR } \\
\text { Average } \pm \text { SEM }\end{array}$ & $\begin{array}{c}\text { DOR } \\
\text { Average } \pm \text { SEM }\end{array}$ & $\begin{array}{c}\text { Value } \\
\mathbf{P}\end{array}$ \\
\hline Detection of first follicles $\geq 4 \mathrm{~mm}$ (days) & $9.58 \pm 0.6$ & $10.8 \pm 1.5$ & $0.3^{b}$ \\
\hline First postpartum ovulation (days) & $21.55 \pm 1.1$ & $48.7 \pm 8.8$ & $0.01^{a}$ \\
\hline Ovulatory follicle diameter (mm) & $18.07 \pm 0.9$ & $23.18 \pm 1.7$ & $0.5^{b}$ \\
\hline Second postpartum ovulation (days) & $47.19 \pm 3.7$ & $69.8 \pm 9.1$ & 0.01 \\
\hline Interval between $1^{\text {st }}$ and $2^{\text {nd }}$ ovulation (days) & $25.65 \pm 3.3$ & $21.1 \pm 0.7$ & $0.4^{b}$ \\
\hline Ovulatory follicle diameter (mm) & $21 \pm 0.8$ & $23.81 \pm 1.9$ & 0.02 \\
\hline Third postpartum ovulation (days) & $67 \pm 4.1$ & $93.14 \pm 13.3$ & 0.01 \\
\hline Interval between $2^{\text {nd }}$ and $3^{\text {rd }}$ ovulation (days) & $20 \pm 1.1$ & $21.43 \pm 1.0$ & $0.5^{b}$ \\
\hline Ovulatory follicle diameter (mm) & $21.81 \pm 0.6$ & $24.8 \pm 3.4$ & $0.03^{\circ}$ \\
\hline Fourth postpartum ovulation (days) & $79.88 \pm 3.2$ & $104.67 \pm 8.1$ & $0.05^{\circ}$ \\
\hline Interval between $3^{\text {rd }}$ and $4^{\text {th }}$ ovulation (days) & $20.69 \pm 1.1$ & $22 \pm 5.1$ & $0.7^{b}$ \\
\hline Ovulatory follicle diameter $(\mathrm{mm})$ & $21.98 \pm 0.9$ & $35.4 \pm 7.4$ & $0.05^{\circ}$ \\
\hline
\end{tabular}

Average \pm SEM values reported; Values for $\mathrm{p}<0.05$ were considered statistically significant; EOR= Early Ovarian Resumption (First Ovulation < $32 \mathrm{~d}$ ); $\mathrm{DOR}=$ Delayed Ovarian Resumption (First Ovulation $>32 \mathrm{~d}$ ) 
Volumen del $\mathrm{CL}$ y niveles de $\mathrm{P}_{4}$ sérica. No se observaron diferencias estadísticas en las concentraciones séricas de $\mathrm{P}_{4}$ entre los animales del grupo ROT comparados con aquellos del grupo ROR, durante los 15 días posteriores a su primera ovulación post parto ( $p>0.05)$; sin embargo, éste último grupo se caracterizó por la presentación de fases luteales prolongadas (niveles sostenidos de $\mathrm{P}_{4} \geq 1 \mathrm{ng} / \mathrm{ml}$ ) por períodos comprendidos entre 24 y 32 días (Figura 1 ).

El volumen máximo del CL fue de $5.000 \pm 400 \mathrm{~mm}^{3}$ entre los días 12 y 16 del ciclo siguiente a la primera ovulación post parto en los animales ROT. Los animales ROR presentaron $\mathrm{CL}$ con duración prolongada, cuyo máximo volumen fue $8.000 \pm 400 \mathrm{~mm}^{3}$ y el cual se mantuvo por más de 30 días posteriores a la primera ovulación $(p<0.05)$ (Figura 2$)$.

Condición corporal. Se observó una disminución en la condición corporal (CC) en todos los animales del estudio durante los primeros $60 \mathrm{dpp}$. El promedio de la CC preparto fue de $3.3 \pm 0.22$ (rango de 2.9 -3.7), mientras que los promedios en los días 28 y 60 post parto fueron de $[2.5 \pm 0.18$ (rango de $1.9-2.9)$ y $2.4 \pm 0.24$ (rango de $1.8-2.8),(p<0.05)]$.

No hubo diferencias estadísticas en la CC preparto entre el grupo ROT ( $3.3 \pm 0.19)$ y ROR $(3.2 \pm 0.27)$ $(p>0.05)$; sin embargo se observaron diferencias entre ellos durante el posparto. Los animales ROR perdieron más CC $(2.3 \pm 0.24)$ que los animales ROT ( $2.5 \pm 0.15)$ cuando la evaluación se hizo al día 28 ( $\mathrm{p} \leq 0.05)$; aunque al día 60 postparto ya no se

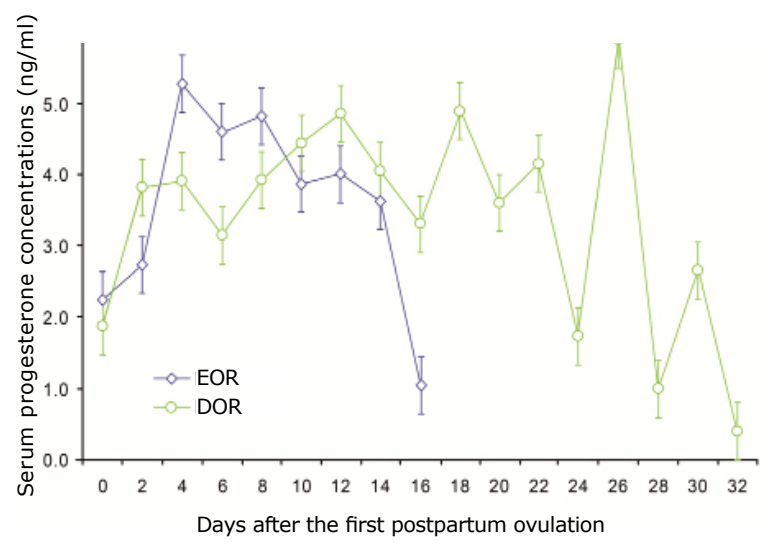

Figure 1. Serum progesterone levels in Holstein cows with early ovarian resumption activity (EOR) restart and delayed ovarian resumption activity (DOR), after the first postpartum ovulation. Serum progesterone concentrations $(\mathrm{ng} / \mathrm{ml}), \pm$ EEP, in animals with EOR $(n=31)$ and DOR $(n=10)$. Data were normalized from the first postpartum ovulation.
$C L$ volume $y$ and serum $P_{4}$ levels. There were no statistical differences in serum $P_{4}$ concentrations amid animals in the EOR group as compared with those of the DOR group, during the 15 days following their first postpartum ovulation $(p>0.05)$; however, the latter group was characterized by prolonged luteal phases (sustained levels of $\mathrm{P}_{4} \geq 1 \mathrm{ng} / \mathrm{ml}$ ) for periods between 24 and 32 days (Figure 1 ).

The maximum $\mathrm{CL}$ volume was $5.000 \pm 400 \mathrm{~mm}^{3}$ between days 12 and 16 of the cycle following the first postpartum ovulation in EOR animals. DOR animals showed $\mathrm{CL}$ with prolonged duration, the maximum volume of which was $8.000 \pm 400$ $\mathrm{mm}^{3}$ and remained for more than 30 days after the first ovulation $(p<0.05)$ (Figure 2$)$.

Body condition. A decrease in the body condition (BC) of all animals in the study was observed during the first $60 \mathrm{dpp}$. The prepartum BC averaged $3.3 \pm 0.22$ (range from 2.9 to 3.7 ), while the averages on days 28 and 60 postpartum were $[2.5 \pm 0.18$ (range from 1.9 to 2.9 ) and $2.4 \pm 0.24$ (range from 1.8 to $2.8),(p<0.05)]$.

There were no statistical differences in the prepartum BC in the EOR $(3.3 \pm 0.19)$ and DOR group ( $3.2 \pm 0.27)(p>0.05)$; however, differences between them during postpartum were observed. DOR animals lost more BC $(2.3 \pm 0.24)$ than EOR animals $(2.5 \pm 0.15)$ when the evaluation was carried out on day

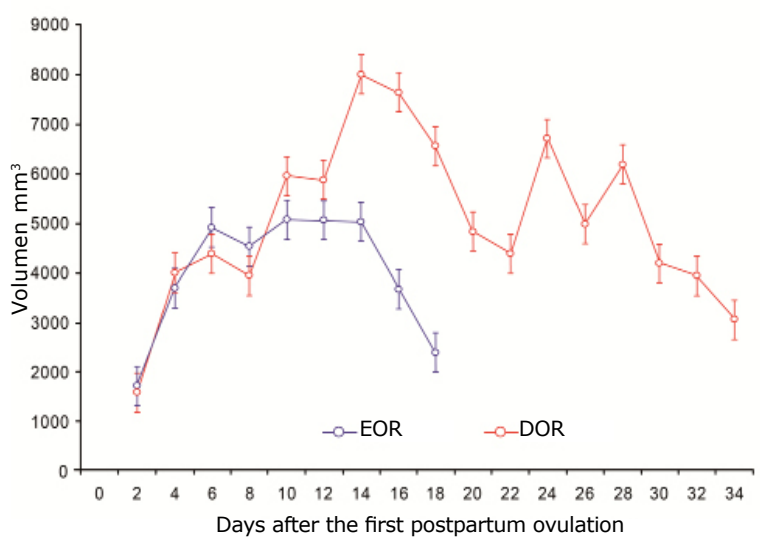

Figure 2. Differences in the average volume of the corpus luteum $\left(\mathrm{mm}^{3}\right)$ after the first postpartum ovulation in Holstein cows under high tropical conditions. Average volumes of corpus luteum $\left(\mathrm{mm}^{3}\right)$, \pm EEP, in animals with early ovarian resumption activity, EOR $(n=31)$ and delayed ovarian resumption activity, DOR $(n=10)$. Data were normalized from the first postpartum ovulation. 
detectó esta diferencia, ROT $(2.3 \pm 0.18)$ vs. ROR $(2.2 \pm 0.19)(p>0.05)$.

Producción de leche. El promedio de producción de leche al día 28, en los animales ROT fue de $32.65 \pm 6.1$ litros, similar al de los animales ROR, que tuvieron un promedio de $33.30 \pm 5.6$ litros $(p>0.05)$. Los promedios de producción al día 60 fueron de $36.61 \pm 6.9$ y $35.50 \pm 4.6$ litros para los animales del grupo ROT y ROR respectivamente $(p>0.05)$. Tampoco se observaron diferencias significativas en las lactancias ajustadas a 305 días para los animales del grupo ROT (8404.9 1619 litros) frente al grupo ROR (8282.4 1535 litros) $(p>0.05)$.

Factores asociados a la primera ovulación post-parto. La prevalencia observada de las patologías asociadas con el periparto fue la siguiente: $34.1 \%$ de los animales presentó fiebre durante su primera semana postparto $(n=14)$; $19.5 \%$ hipocalcemia clínica (vacas caídas) $(n=8)$; $58.5 \%$ hipocalcemia subclínica $(n=24) ; 26.8 \%$ distocia $(n=11) ; 24.3 \%$ retención de placenta $(n=10) ; 14.6 \%$ metritis puerperal $(n=6) ; 36.5 \%$ endometritis $(n=15) ; 29.2 \%$ quistosis ovárica $(n=12) ; 34.1 \%$ mastitis $(n=14)$ y $21.9 \%$ cojera $(n=9)$.

El análisis univariado mostró que la presentación de fiebre durante la primera semana postparto, bajos niveles de calcio sérico durante el mismo período, presentación de enfermedades metabólicas (hipocalcemia o cetosis), aplicación de tratamientos posteriores al parto, presentación de otras patologías del puerperio como retención de membranas fetales, metritis puerperal, mastitis, o quistes ováricos, no estuvieron estadísticamente asociados con la presentación de la primera ovulación postparto y posterior reinicio de la ciclicidad ( $p>0.05)$. Asimismo, la presentación de cetosis fue excluida tanto en el análisis univariado, como del multivariado, debido a que ninguno de los animales arrojó resultados positivos a ella. En segundo lugar se observó que la presentación de distocia (OR 2.2; IC 0.5-10.5; p<0.5), la disminución de la CC (<2.5) (OR 3.3; IC 1.1-13.8; $\mathrm{p}<0.05$ ) y la presencia de cojeras (OR10.3; IC 1.2$92.2 ; p<0.05)$ fueron factores asociados con el retraso en la presentación de la primera ovulación postparto (Tabla 2).

El modelo final del análisis multivariado de regresión logística binaria, determinó que los factores de riesgo asociados al retardo de la primera ovulación postparto fueron, la pérdida de condición corporal hasta alcanzar un puntaje inferior a $2.5(\mathrm{OR}=3.3$, IC $95 \%(1.2-13.3)(\mathrm{p}<0.05)$ y la presentación de cojeras $(O R=9.0$, IC 95\% $(1.2-13.3) \quad(p<0.05)$. (Tabla 3).
28 ( $\mathrm{p} \leq 0.05$ ); although by day 60 postpartum this difference was no longer detected, EOR $(2.3 \pm 0.18)$ vs. DOR $(2.2 \pm 0.19)(p>0.05)$.

Milk production. Milk production on day 28 in EOR animals averaged 32.65 26.1 liters, similar to DOR animals that averaged $33.30 \pm 5.6$ liters $(p>0.05)$. Production averages on day 60 were $36.61 \pm 6.9$ and $35.50 \pm 4.6$ liters for animals of the EOR and DOR group respectively $(p>0.05)$. There were no significant differences in lactations adjusted to 305 days for animals of the EOR group (8.404.9 1.619 liters) as compared with the DOR group (8.282.4 1 1.535 liters) $(p>0.05)$.

Factors associated with the first postpartum ovulation. The prevalence observed of pathologies associated with peripartum was as follows: $34.1 \%$ of animals had fever during their first postpartum week $(n=14) ; 19.5 \%$ showed clinical hypocalcaemia (down cows) $(n=8) ; 58.5 \%$ subclinical hypocalcemia $(n=24) ; 26.8 \%$ dystocia $(n=11)$; $24.3 \%$ retained placenta $(n=10) ; 14.6 \%$ puerperal metritis $(n=6) ; 36.5 \%$ endometritis $(n=15) ; 29.2 \%$ ovarian cystosis $(n=12) ;$ $34.1 \%$ mastitis $(n=14)$ and $21.9 \%$ lameness $(n=9)$.

The univariate analysis showed that fever during the first postpartum week, low serum calcium levels during the same period, metabolic diseases (ketosis or hypocalcemia), application of postpartum treatments, other puerperium pathologies such as retention of fetal membranes, puerperal metritis, mastitis, or ovarian cysts, were not statistically associated with the first postpartum ovulation and subsequent cyclicity resumption ( $p>0.05)$. Likewise, ketosis was excluded both from the univariate and the multivariate analysis, since none of the animals showed positive results. Secondly, it was noted that the presentation of dystocia $(O R=2.2 ; C I 0.5-10.5 ; p<0.5)$, the decrease of $B C(<2.5)(O R=3.3 ; C I 1.1$ $13.8 ; p<0.05)$ and the presence of lameness $(\mathrm{OR}=10.3$; CI 1.2-92.2; $\mathrm{p}<0.05)$ were factors associated with delays in the first postpartum ovulation (Table 2).

The final multivariate binary logistic regression analysis model determined that the risk factors associated with the delay of the first postpartum ovulation were, loss of body condition until reaching a score of less than $2.5(\mathrm{OR}=3.3$, CI 95\% (1.2-13.3) $(\mathrm{p}<0.05)$ and lameness $(O R=9.0$, CI 95\% (1.2-13.3) $(p<0.05)$. (Table 3). 
Table 2. Univariate analysis of variables associated with the first ovulation before day 32 postpartum in high yield dairy Holstein cows in the Sabana de Bogota.

\begin{tabular}{|c|c|c|c|}
\hline Factors & OR & IC 95\% & $\mathbf{P}$ \\
\hline Prepartum body condition & 0.8 & $0.16-4.4$ & 0,840 \\
\hline Body condition on day 32 postpartum $(<2.5)$ & 3.3 & $1.1-13.8$ & $0.041^{*}$ \\
\hline Serum calcium (day 3 postpartum) & 1.1 & $0.26-4.2$ & 0,945 \\
\hline Serum calcium (day 6 postpartum) & 1.6 & $0.3-7.7$ & 0,576 \\
\hline Dystocia & 2.2 & $0.5-10.5$ & $0.029 *$ \\
\hline Number of births & 1.2 & $0.3-5.0$ & 0.79 \\
\hline No postpartum fever (normal $\mathrm{T}^{\circ}$ ) & 1.9 & $0.5-7.3$ & 0.326 \\
\hline Downer & 0.8 & $0.2-3.9$ & 0.817 \\
\hline Postpartum treatments & 1.7 & $0.5-6.0$ & 0.397 \\
\hline Retained placenta & 2.5 & $0.5-11.4$ & 0.233 \\
\hline Puerperal metritis & 1.9 & $0.3-11.7$ & 0.489 \\
\hline Milk production ( $\geq 35$ Liters per day) & 1.1 & $0.26-4.2$ & 0.94 \\
\hline Milk production (305 days) & 0.6 & $0.2-2.1$ & 0.427 \\
\hline Lameness & 10.3 & $1.2-92.2$ & $0.016^{*}$ \\
\hline Mastitis & 1.9 & $0.5-7.3$ & 0.326 \\
\hline Ovarían Cysts & 1.4 & $0.3-5.0$ & 0.699 \\
\hline
\end{tabular}

* Values for $\mathrm{p} \leq 0.05$ were considered statistically significant.

Table 3. Multivariate analysis of factors associated with the first postpartum ovulation before day 32 in Holstein cows in the Sabana de Bogota.

\begin{tabular}{cllc}
\hline Factor & OR & CI 95\% & P \\
\hline Body condition below 2.5 (day 32 pp) & 3.3 & $1.2-13.3$ & 0.048 \\
Lameness & 9.0 & $1.2-85.2$ & 0.05 \\
\hline
\end{tabular}

* Values for p£0.05 were considered statistically significant.

\section{DISCUSIóN}

La presente investigación evaluó la dinámica folicular en bovinos lecheros bajo condiciones de trópico alto, antes y después de la primera ovulación post parto, así como el grado de asociación con algunas de las patologías más frecuentemente reportadas durante el periparto. Los resultados del estudio permitieron dilucidar los patrones de reactivación ovárica y determinar algunos factores de riesgo asociados con la reactivación ovárica postparto bajo dichas condiciones.

La emergencia de la primera onda folicular se observó en promedio al día $10.1 \pm 3.45$ (rango de 4-22) post-parto, concordando con resultados previos que han reportado la aparición del primer folículo dominante, que no siempre es ovulatorio, a los $7.0 \pm 0.9 \mathrm{~d}(26)$ y a los $11.6 \pm 2.0 \mathrm{~d}$ (rango de $5-39)$ después del parto $(17,27)$. En este estudio, dieciséis de los animales (39.2\%) presentaron la emergencia de la primera onda de desarrollo folicular temprano (días 4 a 8), diecinueve de ellos $(46.3 \%)$, entre los días 9 y 13 y finalmente seis animales $(14.6 \%)$ lo hicieron entre los 14 y 22 días postparto; mostrando una distribución acorde con los resultados de otros estudios (5-6).

El promedio de los días a la primera ovulación en el presente estudio fue de $24.26 \pm 7.84$; estos

\section{DISCUSSION}

This research evaluated the follicular dynamics in dairy cattle under high tropical conditions, before and after the first postpartum ovulation, as well as the degree of association with some of the most frequently pathologies reported during peripartum. The results of the study allowed to elucidate ovarian resumption patterns and determine some risk factors associated with postpartum ovarian resumption under such conditions.

The emergence of the first follicular wave was observed on average on day $10.1 \pm 3.45$ (range from 4 to 22) postpartum, this being consistent with previous results that reported the emergence of the first dominant follicle, which is not always ovulatory, at day $7.0 \pm 0.9$ (26) and $11.6 \pm 2.0$ (range from 5 to 39) after partum $(17,27)$. In this study, sixteen of the animals $(39.2 \%)$ showed the emergence of the first early follicular wave development (days 4 to 8 ), nineteen of them (46.3\%) between days 9 and 13 , and finally six animals (14.6\%) between day 14 and 22 postpartum; showing a distribution consistent with the results of other studies (5-6).

The days to the first ovulation in this study averaged $24.26 \pm 7.84$; these results are 
resultados son un poco menores a los descritos por otros investigadores en latitudes diferentes (27), y bajo distintos sistemas productivos (pastoreo vs. estabulaciones).

El porcentaje de detección de estros observados en este estudio fue del $36 \%$, lo cual coincide con otros trabajos (28). La proporción de animales clasificada en anestro, utilizando para ello la presentación de estro detectado, fue del 64\% (26/41), esto difiere del resultado obtenido de clasificar los animales basándose en los hallazgos del ultrasonido (presencia de $\mathrm{CL}$ ) y con la medición de $\mathrm{P}_{4}$, lo cual arrojó resultados más bajos, correspondiendo al $11 \%$ (5/41) de los animales. Esta problemática contribuye a incrementar los porcentajes de animales que comúnmente son reportados en anestro, cuando en ocasiones se puede tratar de problemas asociados con una inadecuada detección de estros, y no estrictamente por la presentación de ovarios inactivos o anestro verdadero (3), o con alteraciones en el desarrollo folicular, como anovulación, y ausencia de $\mathrm{CL}$, situación que también ha sido planteada por otros autores (29). Es posible especular que estas diferencias se pueden atribuir a la presentación de ovulaciones sin manifestación de signos de estro (24), o a la presentación de estros de baja intensidad y corta duración, haciendo que su expresión y comportamiento no sea evidente (23), debido probablemente a los cambios en el metabolismo de las hormonas esteroidales y el fluido folicular, propuestos por algunos autores en vacas de alta producción lechera $(15,22)$.

El volumen del CL en los animales con ROR fue mayor que en aquellos con ROT, lo cual no parece afectar las concentraciones de $\mathrm{P}_{4}$ durante los primeros 16 días posteriores a la primera ovulación, debido probablemente a que sus niveles de producción fueron altos y por tanto la progesterona se metabolizaría de manera similar (21). Tampoco se observaron diferencias estadísticas en las concentraciones séricas de $\mathrm{P}_{4}$ entre los animales con ROT y ROR, durante el mismo período de tiempo ( $p>0.05)$; sin embargo, éste último grupo se caracterizó por la presentación de fases luteales prolongadas. Estos datos concuerdan con un reporte previo (17) en el cual dos terceras partes de los animales presentaron reactivación de la ciclicidad ovárica post parto retardada.

En este estudio se pudo observar una disminución en el puntaje de CC en las vacas durante los primeros 60 días postparto, lo cual no pareció afectar la ocurrencia de la primera onda folicular, ya que se observó que todos los animales iniciaron el reclutamiento de folículos antes del día 20 . Por el contrario, el retorno a la ciclicidad luego de la primera ovulación postparto se vio afectado pudiéndose observar que los animales cuya CC descendió a un valor menor o igual a 2.5 al día 32 slightly lower than those described by other researchers in different latitudes (27), and under different production systems (grazing vs. housing).

The percentage of detection of estrus observed in this study was $36 \%$, which coincides with other studies (28). The proportion of animals classified in anestrus, using for this purpose the estrus detected, was $64 \%$ (26/41), this differs from the result obtained by classifying animals based on ultrasound findings ( $C L$ present) and with the measurement of $\mathrm{P}_{4}$, which yielded lower results corresponding to $11 \%$ (5/41) of animals. This problem contributes to increase the percentage of animals that commonly are reported in anestrus, when sometimes there can be problems associated with the inadequate detection of estrus, and not strictly by inactive ovaries or true anestrus (3), or alterations in the follicular development, such as anovulation and absence of $C L$, a situation that has also been raised by other authors (29). It is possible to speculate that these differences can be attributed to ovulations without manifestation of estrus signs (24), or the presentation of low-intensity and shortduration estrus, making their expression and behavior not evident (23), probably due to changes in the metabolism of steroidal hormones and follicular fluid, proposed by some authors in high yield dairy cows $(15,22)$.

The CL volume in animals with DOR was higher that those with EOR, which does not seem to affect $\mathrm{P}_{4}$ concentrations during the first 16 days after the first ovulation, probably due to the fact that production levels were high and therefore progesterone would metabolize in a similar manner (21). There were no statistical differences in serum concentrations of $P_{4}$ among animals with EOR and DOR during the same period of time $(p>0.05)$; however, the latter group was characterized by prolonged luteal phases. These data are consistent with a previous report (17), in which two-thirds of the animals presented delayed postpartum ovarian cyclicity resumption.

In this study was observed a decrease in the BC score of cows during the first 60 days postpartum, which did not appear to affect the occurrence of first follicular wave, since it was observed that all animals started producing follicles before day 20. Conversely, the return to cyclicity after the first postpartum ovulation was affected, allowing to observe that animals whose BC dropped to a value less than or equal to 2.5 on day 32 postpartum, were 3.3 times more likely to have delayed ovulation 
post parto, tuvieron 3.3 veces más probabilidades de presentar ovulación retardada $(\mathrm{OR}=3.3$, IC 95\% $(1.2-13.3)(p<0.05)$. Este período es crítico debido a la mayor demanda de nutrientes requeridos para la producción de leche (2), y la movilización de grasa de las reservas corporales por el desfase que ocurre entre las demandas metabólicas y el consumo de materia seca en el postparto temprano $(15,29)$, especialmente si el manejo nutricional durante el período de transición no es adecuado (1) situación común en algunos sistemas de pastoreo.

En el presente estudio el principal problema encontrado en los animales estuvo relacionado con las diversas alteraciones en la ciclicidad posterior a la primera ovulación, dentro de las cuales se pudo observar en primer lugar anovulación por condiciones quísticas del ovario; en algunos casos probablemente asociados con disturbios o desequilibrios energéticos o nutricionales $(2,29)$. En segundo lugar, se observó la incapacidad del folículo para alcanzar diámetro ovulatorio, situación que se ha reportado asociada con folículos que alcanzan el estado de dominancia pero no producen concentraciones suficientes de $\mathrm{E}_{2}$ capaces de estimular los picos preovulatorios de LH $(3,28)$, y que probablemente puedan estar también relacionadas con las fases luteales prolongadas. Por ultimo, se observó anovulación por persistencia del $\mathrm{CL}$, posiblemente como consecuencia de la presentación de patologías. En ese sentido, se ha descrito que la primera fase de reactivación ovárica suele iniciarse desde la primera semana post-parto en animales con parto normal, pero se retrasa en aquellos que han sufrido partos distócicos, retención de membranas fetales y enfermedades metabólicas que impiden la secreción normal de prostaglandinas, manteniendo niveles altos de progesterona permitiendo la extensión de la fase luteal (16). De manera interesante en este estudio, la presentación de distocia fue un factor asociado con el retraso de la primera ovulación $(p<0.05)$ en el análisis univariado, sin embargo, y probablemente por la baja frecuencia de presentación de casos, no resultó asociado en el modelo final, pero bien merece ser considerado como un factor de riesgo.

Igualmente se observó que aquellos animales que presentaron cojeras tuvieron nueve veces más posibilidades de presentar ROR OR=9, IC 95\% $(1.2-85.2)(p \leq 0.05)$; lo cual coincide con reportes previos $(30,7)$. Otras patologías como la mastitis (8), metritis puerperal (16) y distocias (9) han sido asociadas con alteración del desempeño reproductivo en bovinos (1). La explicación más posible de este fenómeno se ha relacionado con niveles elevados de citoquinas, proteínas de fase aguda y cortisol, los cuales tienen un efecto negativo sobre la oportuna liberación de LH y progesterona (31) alterando el microambiente folicular.
$(O R=3.3$, CI 95\% $(1.2-13.3)(p<0.05)$. This period is critical due to the increased demand for nutrients required for milk production (2), and the mobilization of fat from body reserves by the gap occurring between metabolic demands and the intake of dry material in early postpartum $(15,29)$, especially if the nutritional handling during the transition period is not appropriate (1), a common situation in certain grazing systems.

In this study the main problem found in animals was associated with various alterations in cyclicity subsequent to the first ovulation, where anovulation could be first observed by cystic ovary conditions; in some cases probably associated with energy or nutritional disturbances or imbalances $(2,29)$. Secondly, the inability of the follicle to achieve ovulatory diameter was observed, a situation that has been reported as associated with follicles that reach dominance state but do not produce sufficient $\mathrm{E}_{2}$ concentrations capable of stimulating preovulatory LH highs (3, 28 ), and may probably be also related to prolonged luteal phases. Finally, anovulation by $\mathrm{CL}$ persistence was observed, possibly as a result of the emergence of pathologies. In this regard, it has been described that the first ovarian resumption phase usually starts from the first postpartum week in animals with normal calving, but is delayed in those that have suffered dystocic calving, retention of fetal membranes and metabolic diseases that prevent the normal secretion of prostaglandins, maintaining high progesterone levels and allowing the extension of the luteal phase (16). Interestingly in this study, the presentation of dystocia was a factor associated with the delay in the first ovulation $(p<0.05)$ in univariate analysis, however, and probably due to the low frequency of cases, it was not associated in the final model, but it deserves to be considered as a risk factor.

It was also noted that animals with lameness were nine times more likely to show DOR $\mathrm{OR}=9$, CI 95\% (1.2-85.2) ( $\mathrm{p} \leq 0.05)$; which coincides with previous reports $(30,7)$. Other pathologies such as mastitis (8), puerperal metritis (16) and dystocia (9) have been associated with the alteration of the reproductive performance of cattle (1). The most possible explanation of this phenomenon has been associated with elevated levels of cytokines, acute-phase proteins and cortisol, which have a negative effect on the timely release of $\mathrm{LH}$ and progesterone (31) altering the follicular microenvironment. 
Los resultados obtenidos bajo las condiciones del presente trabajo mostraron que la buena condición corporal durante el periparto es un factor que favorece la ovulación temprana, mientras que las cojeras son un factor de riesgo para que se presenten ovulaciones tardías en los sistemas de pastoreo especializado en trópico de altura.

\section{Agradecimientos}

A la ganadería Inversiones Los Sauces Bermúdez y Cía. S.C.A., a la Dra. Ingrid Guerra, y todo el personal de las fincas "El Coclí" y "Los Sauces" por su colaboración.
The results obtained under the conditions of this study showed that proper body condition during peripartum is a factor that favors early ovulation, while lameness is a risk factor for the occurrence of late ovulation in specialized grazing systems in high tropical areas.

\section{Acknowledgements}

To Ganaderia Inversiones Los Sauces Bermudez y Cia. S.C.A., to Dr. Ingrid Guerra, all the personnel of the farms "El Cocli" and "Los Sauces" for their collaboration.

\section{REFERENCES}

1. Wullepit N, Hostens M, Ginneberge C, Fievez V, Opsomer G, Fremaut D, et al. Influence of a marine algae supplementation on the oxidative status of plasma in dairy cows during the periparturient period. Prev Vet Med 2012; (103):298-303.

2. Shrestha HK, Nakao T, Suzuki T, Akita M, Higaki T. Relationships between body condition score, body weight, and some nutritional parameters in plasma and resumption of ovarian ciclicity postpartum during pre-service period in high producing dairy cows in a subtropical region in Japan. Theriogenology 2005; (64):855-866.

3. Gümen $A$, Wiltbank MC. Length of progesterone exposure needed to resolve large follicle anovular conditions in dairy cows. Theriogenology 2005; (63):202-218.

4. Vassena R, Adams GP, Mapletoft R, Pierson RA, Singh J. Ultrasound image characteristics of ovarian follicles in relation to oocyte competence and follicular status in cattle. Anim Reprod Sci 2003; (76):25-41.

5. Noseir W. Ovarian follicular activity and hormonal profile during estrous cycle in cows: the development of 2 versus 3 waves. Reprod Biol Endocrinol 2003; (1):2-6.

6. Adams GP, Jaiswal R, Singh J, Malhi P. Progress in understanding ovarian follicular dynamics in cattle. Theriogenology 2008; (69):72-80.

7. Garbarino EJ, Hernández JA, Shearer JK, Risco CA, Thatcher WW. Effect of lameness on ovarian activity in postpartum holstein cows. J Dairy Sci 2004; (87):4123-4131.
8. Santos JE, Cerri RL, Ballou MA, Higginbotham $\mathrm{GE}$, Kirk JH. Effect of timing of first clinical mastitis occurrence on lactational and reproductive performance of Holstein dairy cows. Anim Reprod Sci 2004; (80):31-45.

9. Ahmadzadeh A, Frago F, Shafii B, Dalton JC, Price JC, McGuire MA. Effect of clinical mastitis and other diseases on reproductive performance of Holstein cows. Anim Reprod Sci 2007; (10): 1016-24.

10. Pinzón C. "Evaluación de los niveles de progesterona y la dinámica folicular en vacas Holstein postparto en el trópico bajo (Estudio de caso)". Tesis de Grado; Bogotá. Universidad Nacional de Colombia. Facultad de Medicina Veterinaria y de Zootecnia, 2001.

11. Olivera M, Henao D, Carrillo LM. Comportamiento durante el calor y dinámica folicular interestral en vacas BON (Blanco Orejinegro). Rev Col Cienc Pec 2003; 17(1):39-44.

12. Ceballos A, Villa NA, Betancourth T, Roncancio D. Determinación de la concentración de calcio, fósforo y magnesio en el periparto de vacas lecheras en Manizales, Colombia. Rev Col Cienc Pec 2004; 17(2):125-133.

13. Galvis RD, Agudelo D, Saffon A. Condición corporal, perfil de lipoproteínas y actividad ovárica en vacas Holstein en lactancia temprana. Rev Col Cienc Pec 2007; 20(1):6-29.

14. Instituto Geográfico Agustín Codazzi (IGAC). Cundinamarca, características geográficas. Santafé de Bogotá. 2004. 
15. Leroy JL, VanholderT, Delanghe JR, Opsomer G, Van Soom A, Bols PE, et al. Metabolic changes in follicular fluid of the dominant follicle in high Fielding Dairy cows early postpartum. Theriogenology 2004; (62):1131-1143.

16. Walsh RB, Kelton DF, Duffield TF, Leslie KE, Walton JS, LeBlanc SJ. Prevalence and risk factors for postpartum anovulatory condition in dairy cows. J Dairy Sci 2007; (90):315-324.

17. Shrestha HK, Nakao T, Higaki T, Suzuki T, Akita, M. Resumption of postpartum ovarian cyclicity in high producing Holstein cows. Theriogenology 2004; 61(4):637-649.

18. Zambrano JL. Studies in the superovulatory response to gonadotropins and folliculogenesis of water buffalo (Bubalus bubalis). [Tesis de Doctorado] Davis, Estados Unidos: Universidad de California; 2009.

19. Fortune JE, Rivera GM, Yang MY. Follicular development: the role of the follicular microenvironment in selection of the dominant follicle. Anim Rep Sci 2004; (82):109-126.

20. Hannan MA, Fuenzalida MJ, Siddiqui MA, Shamsuddin M, Beg MA, Ginther OJ. Diurnal variation in $\mathrm{LH}$ and temporal relationships between oscillations in $\mathrm{LH}$ and progesterone during the luteal phase in heifers. Theriogenology 2010; (74):1491-1498.

21. López H, Sartori R, Wiltbank M. Reproductive hormones and follicular growth during development of one or multiple dominant follicles in cattle. Biol Reprod 2005; (72): 788-795.

22. Wiltbank W, López H, Sartori R, Sangsritavng $S$, Gümen A. Changes in reproductive physiology of lactating dairy cows due to elevated steroid metabolism. Theriogenology 2006; (65):17-29.

23. López $H$, Sartori $R$, Wiltbank $M$. Type of estrus cows. Theriogenology 2004; (81):209-223.
24. Palmer M, Olmos G, Boyle L, Mee J. Estrus detection and estrus characteristics in housed and pastured Holstein-Friesian cows. Theriogenology 2010; (74):255-264.

25. Pérez-Marin CC, España F. Oestrus expression and ovarian function in repeat breeder cows, monitored by ultrasonography and progesterone assay. Reprod Dom Anim 2007; (42):449-456.

26. Tanaka T, Arai M, Ohtani S, Uemura S, Kuroiwa $\mathrm{T}$, Kim S, et al. Influence of parity on follicular dynamics and resumption of ovarian cycle in postpartum dairy cows. Anim Reprod Sci 2008; (108):134-143.

27. Sakaguchi M, Sasamoto Y, Suzuki T, Takahashi Y, Yamada Y. Postpartum ovarian follicular dynamics and estrous activity in lactating dairy cows. J Dairy Sci 2004; (87):2114-2121.

28. Lopez H, Satter LD, Wiltbank MC. Relationships between level of milk production and estrous behavior of lactating dairy cows. Anim Reprod Sci 2004; (81):209-223.

29. Reist $M$, Erdin $D$, VonEuw $D$, Tschümperlin $K$, Leuenberger $\mathrm{H}$, Hammon $\mathrm{H}$, et al. Postpartum reproductive function: association with energy, metabolic and endocrine status in high yielding dairy cows. Theriogenology. 2003; (59): 1707-1723.

30. Garbarino EJ, Hernandez JA, Shearer JK, Risco CA, Thatcher WW. Effect of lameness on ovarian activity in postpartum Holstein cows. J Dairy Sci 2004; (87):4123-4131.

31. Bertoni G, Trevisi E, Han X, Bionaz M. Effects of inflammatory conditions on liver activity in puerperium period and consequences for performance in Dairy cows. J Dairy Sci 2008; (91):3300-3310. 